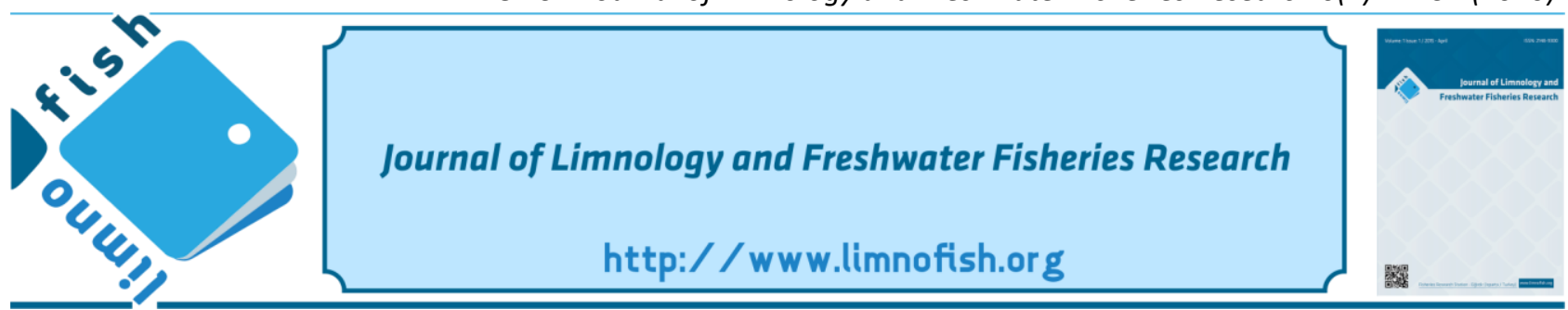

\title{
Testing the Antimicrobial Effects of Some Hydrosols on Food Borne-Pathogens and Spoilage Bacteria
}

\author{
Emre YAVUZER ${ }^{1 * i D}$, Esmeray KULEY BOĞA ${ }^{2}$ \\ ${ }^{1}$ Department of Food Engineering, Faculty of Engineering and Architecture, Kırşehir Ahi Evran University, 40300, Kırşehir, \\ Turkey \\ ${ }^{2}$ Department of Seafood Processing Technology, Faculty of Fisheries, Cukurova University, 01330, Adana, Turkey
}

\section{A B STRACT}

The antimicrobial activity of five hydrosols made from orange peel, pomegranate peel, shaddock peel, mandarin peel, and thyme plant was tested by microdilution and disc diffusion methods against 3 foodborne bacteria (Staphylococcus aureus, Salmonella Parathyphi A and Klebsiella pneumoniae) and 3 fish spoilage bacteria (Vibrio vulnificus, Pseudomonas luteola, and Photobacterium damselae). $S$. Parathyphi A was one of the most susceptible bacteria against all hydrosols tested mainly pomegranate, thyme and shaddock peel (with more than $10.5 \mathrm{~mm}$ inhibition zone). Inhibition zones on the growth of S. aureus were only observed from hydrosols of thyme and mandarin peel. Hydrosols made from orange and mandarin peel were effective on inhibition of the growth of fish spoilage bacteria. Minimum inhibitory concentration (MIC) and minimum bactericidal concentration (MBC) of hydrosols were generally 50 and $>50 \mathrm{mg} / \mathrm{mL}$, respectively. These results show that thyme and pomegranate peel hydrosols had the strongest antimicrobial effects against test bacteria, although the effect of waste hydrosols vary depending on bacterial strains

Keywords: Hydrosols, antimicrobial effect, foodborne pathogens, fish spoilage bacteria
ARTICLE INFO

\section{RESEARCH ARTICLE}

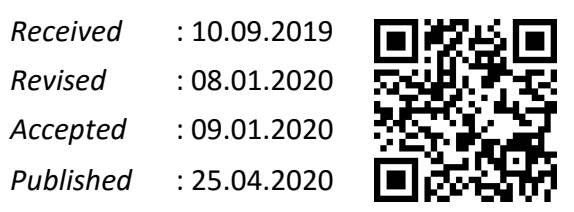

DOI:10.17216/LimnoFish.618101

* CORRESPONDING AUTHOR

emreyavuzer@gmail.com

Phone : +90 3862805409

Bazı Hidrosollerin Gıda Kaynaklı Patojen ve Bozulma Etmeni Bakteriler Üzerindeki Antimikrobiyal Etkilerinin Analizi

Öz: Portakal kabuğu, nar kabuğu, şadok kabuğu, mandalina kabuğu ve kekik bitkisinden elde edilen beş hidrosolün 3 gıda kaynaklı bakteri (Staphylococcus aureus, Salmonella Parathyphi A ve Klebsiella pneumoniae) ve 3 balık bozucu bakterileri (Vibrio vulnificus, Pseudomonas luteola ve Photobacterium damselae) üzerindeki antimikrobiyal aktivitesi, mikrodilüsyon ve disk difüzyon yöntemleriyle test edildi. $S$. Parathyphi A, özellikle nar, kekik ve şadok kabuğundaki (10,5 mm inhibisyon zonuyla) test edilen tüm hidrosollere karşı en duyarlı bakterilerden biriydi. S. aureus' un gelişimi üzerindeki inhibisyon bölgeleri, sadece kekik ve mandalina kabuğunun hidrosollerinde gözlendi. Portakal ve mandalina kabuğundan üretilen hidrosoller, balıklarda bozulma bakterilerinin büyümesinin inhibe edilmesinde etkili olmuştur. Hidrosollerin minimum inhibitör konsantrasyon (MIC) ve minimum bakteri öldürücü konsantrasyonları (MBC) genel olarak sırasıyla 50 ve $>50 \mathrm{mg} / \mathrm{mL}$ idi. Bu sonuçlar, kekik ve nar kabuğu hidrosollerinin test bakterilerine karşı en güçlü antimikrobiyal etkilere sahip olduğunu göstermektedir ancak atık hidrosollerin etkisi bakteri suşlarına bağlı olarak değişmektedir.

Anahtar kelimeler: Hidrosoller, antimikrobiyal etki, gıda kaynaklı patojenler, balıklarda bozucu bakteriler

How to Cite

Yavuzer E, Kuley Boğa E. 2020. Testing the Antimicrobial Effects of Some Hydrosols on Food Borne-Pathogens and Spoilage Bacteria. LimnoFish. 6(1): 47-51. doi: 10.17216/LimnoFish.618101

\section{Introduction}

Studies on alternative natural antimicrobials to protect food and human health are increasing, as the resistance of bacteria to antibiotics poses a global problem. Nowadays, studies generally focus on plant materials and their oils or extracts (Sabo and
Knezevic 2019). Residual hydrosols after oil extraction or plant extraction are considered as waste material. Hydrosols (or hydrolates or aromatic waters) are known as the secondary compounds of steam distillation of plants, performed to obtain essential oils (D'Amato et al. 2018). Hydrosols have 
been used as decontamination agents (Öztürk et al. 2016) or antioxidant and antibacterial agents (Shen et al. 2017), although it is thought that there will be nothing left after removing the pulp and oil from a plant. The use of hydrosols as antimicrobial or disinfectant is very important because they are cheap and even waste.

Since mandarin and thyme oil are used extensively in the food and pharmaceutical industry, the hydrosols of these plants appear as by-products. However, the hydrosols of oil-free plants such as pomegranate peel, shaddock peel, and orange peel may have positive effects because hydrosols have colloidal suspensions of volatile oils and watersoluble components obtained by steam distillation or hydro distillation from plants. The lavender hydrosol is reported to contain linalool $(26.5 \%)$, borneol $(9.0 \%)$, cis-linalool oxide $(6.6 \%)$, trans-linalool oxide (5.2\%) (Śmigielski et al. 2013), whilst thyme hydrosol has carvacrol (48.30\%) and thymol (17.55\%) (D'Amato et al. 2018).

Shaddock also is known as Chinese grapefruit, is a species of the Citrus genus of the citrus family of citrus fruits. Shaddock juice is used in the treatment of hypertension and cardiovascular diseases (Oboh et al. 2014) and it was reported that shaddock bark can be used in the treatment of diabetes (Oboh and Ademosun 2011). Also, studies about pomegranate peel have been made in recent years. Yang et al. (2018) reported that pomegranate peel pectin can be used as an effective emulsifier. Ali et al. (2019) found that pomegranate peel acted as antimicrobial and reinforcing agents for a starch film. Besides, there are many studies on the phenolic components and antioxidant effects of pomegranate peel extract (Zhai et al. 2018; Wu et al. 2019; Rajha et al. 2019). There are many studies regarding waste of orange and mandarin peels that yielded positive results as biodiesel, a natural antioxidant and antimicrobial (Saleem and Saeed, 2020; Kumar et al. 2020; Alexandre et al. 2019).

However, there is limited information on the use of hydrosol as an antimicrobial agent. Thus, the study aimed to determine the use of plant extract or oil byproduct known as hydrosol as an alternative antimicrobial agent.

\section{Materials and Methods}

Collection and preparation of plant materials

Plants were collected from various locations of Turkey: orange (Citrus sinensis) and pomegranate (Punica granatum) peels from Kursehir, shaddock (Citrus maxima) peel from Adana, thyme plant (Thymus vulgaris) from Konya, mandarin (Citrus reticulate) peel from Nigde. Shells of fruits were peeled manually with a knife and dried with sunlight under sterile laboratory conditions.

\section{Preparation of Hydrosols}

The thyme, orange, pomegranate, shaddock and mandarin peel oil were separated by hydro distillation, using an industrial type of Clevenger device for $4 \mathrm{~h}$. After removal of oils, hydrosols were taken from clevenger faucet and put into sterile glass jars. The hydrosols were allowed to cool at room temperature and then kept in the refrigerator until analysis day.

\section{Tested Bacteria}

Staphylococcus aureus ATCC29213 and Klebsiella pneumoniae ATCC700603, which were provided from the American Type Culture Collection (Rockville, MD, USA), and Salmonella Paratyphi A (NCTC13) which was obtained from the National Collection of Type Cultures (London, UK) were used as food-borne pathogens. Vibrio vulnificus, Pseudomonas luteola and Photobacterium damselae which were isolated from spoiled fish were obtained from the Cukurova University, Faculty of Fisheries in Adana, Turkey.

\section{Disc Diffusion Method}

The antimicrobial activity of five hydrosols was determined using the disc diffusion method of Murray et al. (1995). Nutrient agar was employed as the standard test medium for bacterial growth. The agar plate was spread with the inoculum having $10^{8}$ $\mathrm{cfu} / \mathrm{mL}$ pathogenic bacteria. Fifty microliters of undiluted hydrosols were pipetted on sterile filter paper discs (diameter $6 \mathrm{~mm}$ ), which were permitted to dry in an open sterile petri dish in a biological safety cabinet with vertical laminar flow. Paper discs were set on the inoculated agar surfaces. After incubation at $37{ }^{\circ} \mathrm{C}$ for $18-24 \mathrm{~h}$ for bacteria, diameters $(\mathrm{mm})$ of the zones of bacterial inhibition minus the disc diameter were determined. Each test was carried out in triplicate and the results were assessed for statistical significance. Vancomycin and tetracycline antibiotics with positive responses were utilized as the control of Gram-positive and Gramnegative bacteria.

\section{Determination of minimum inhibitory and bactericidal concentrations}

Minimum inhibitory concentration (MIC) and minimum bactericidal concentrations (MBC) of hydrosols against bacteria were determined according to the Clinical and Laboratory Standards Institute's methods (2008). One milliliter of plant hydrosols (with a stock solution of $50 \mathrm{mg} / \mathrm{mL}$ ) was added to the first tube in each series and subsequently, two-fold serially diluted with Mueller 
Hinton Broth (MHB). The inoculum suspension $(1 \mathrm{~mL})$ of each bacterial strain $\left(10^{6} \mathrm{cfu} / \mathrm{mL}\right)$ was then added in each tube containing hydrosols and MHB. The final concentrations of the extract were 50, 25, $12.5,6.25,3.125,1.56,0.78,0.39,0.19 \mathrm{mg} / \mathrm{mL}$. The tubes were incubated at $35^{\circ} \mathrm{C}$ for $18-24$ hours after which the MIC was recorded. MBC was determined by subculturing the contents of tubes of MIC showing no growth.

\section{Statistical analysis}

SPSS 22 version software (Chicago, Illinois, USA) used for one-way variance analysis (ANOVA) and the Duncan's Multiple Range Test. Calculations were done in triplicate and comparisons at $\mathrm{p}$-value of $<0.05$ were carried out to point out significant differences.

\section{Results}

\section{Inhibition zones of hydrosols}

Inhibition zones of hydrosols against food-borne pathogens and fish spoilage bacteria were given in Table 1 . The growth of $S$. aureus was inhibited by thyme and mandarin peel hydrosol, with inhibition zones of 7.5- and 6.63-mm. S. aureus was resistant to orange, pomegranate and shaddock peel hydrosols as well as vancomycin antibiotics. S. Parathyphi A was the most susceptible bacteria against all hydrosols. The highest inhibitory effects were found from pomegranate and thyme hydrosols ( 15.50 vs. 11.25 $\mathrm{mm})$.

\section{Minimum inhibitory and bactericidal concentrations of hydrosols}

Table 2 shows minimum inhibitory concentrations (MIC) of hydrosols against bacteria. All bacteria tested showed $>50 \mathrm{mg} / \mathrm{mL}$ minimum bactericidal concentration (MBC-data not shown). Fish spoilage bacteria generally survived up to 25 $\mathrm{mg} / \mathrm{mL}$, although MIC of $P$. luteola was above 50 $\mathrm{mg} / \mathrm{mL}$ towards hydrosols of pomegranate peel and shaddock peel.

\section{Discussion}

Pomegranate and thyme hydrosols were also effective on inhibition of $K$. pneumoniae growth, whereas the bacteria showed resistance against vancomycin antibiotics. Although mandarin peel suppressed the growth of all bacteria tested, it was ineffective on inhibition of $K$. pneumoniae. Moon et al. (2006) reported that lavender hydrosols did not have any antibacterial activity against Streptococcus pyogenes, S. aureus MRSA, Citrobacter freundii, Proteus vulgaris, E. coli, and Propionibacterium acnes.

P. luteola is an aerobic, gram-negative rod and opportunist bacterium that can cause high mortality, especially in fish. Altinok et al. (2007) reported that $P$. luteola caused the $40 \%$ death of fish in a commercial rainbow trout farm. It is also known to pose a danger to hospital-type infections (Otto et al. 2013: Çiçek et al. 2016). Among fish spoilage bacteria, $P$. luteola was the most susceptible bacteria towards hydrosols, but $V$. vulnificus was the lowest. The highest inhibition zones were observed for thyme $(9.38 \mathrm{~mm})$ and pomegranate peel $(8.50 \mathrm{~mm})$ hydrosols.

Table 1. Antimicrobial sensitivity of some hydrosols determined by disc diffusion method.

\begin{tabular}{|c|c|c|c|c|c|c|c|}
\hline \multicolumn{8}{|c|}{ Inhibition Zone Diameter (mm) } \\
\hline Bacteria & & & Hydrosols & & & Anti & otics \\
\hline Pathogen bacteria & Orange peel & Thyme & $\begin{array}{c}\text { Pomegranate } \\
\text { peel }\end{array}$ & $\begin{array}{c}\text { Shaddock } \\
\text { peel }\end{array}$ & $\begin{array}{l}\text { Mandarin } \\
\text { peel }\end{array}$ & Vancomycin & Tetracycline \\
\hline Staphylococcus aureus & $0.00 \pm 0.00^{\mathrm{c}}$ & $7.50 \pm 0.50^{\mathrm{b}}$ & $0.00 \pm 0.00^{\mathrm{c}}$ & $0.00 \pm 0.00^{\mathrm{c}}$ & $6.63 \pm 0.41^{b}$ & $0.00 \pm 0.00^{\mathrm{c}}$ & $23.50 \pm 2.29^{\mathrm{a}}$ \\
\hline Salmonella Paratyphi A & $9.55 \pm 0.55^{\mathrm{d}}$ & $11.25 \pm 0.83^{\mathrm{d}}$ & $15.50 \pm 0.50^{\mathrm{c}}$ & $10.50 \pm 0.50^{\mathrm{d}}$ & $7.00 \pm 0.58^{\mathrm{e}}$ & $18.50 \pm 1.29^{\mathrm{b}}$ & $22.45 \pm 1.37^{\mathrm{a}}$ \\
\hline Klebsiella pneumoniae & $0.00 \pm 0.00^{\mathrm{d}}$ & $6.25 \pm 0.43^{\mathrm{c}}$ & $9.50 \pm 0.50^{\mathrm{b}}$ & $0.00 \pm 0.00^{\mathrm{d}}$ & $0.00 \pm 0.00^{\mathrm{d}}$ & $0.00 \pm 0.00^{\mathrm{d}}$ & $22.00 \pm 1.41^{\mathrm{a}}$ \\
\hline $\begin{array}{l}\text { Spoiling bacteria } \\
\text { Vibrio vulnificus }\end{array}$ & $5.50 \pm 0.50^{\mathrm{d}}$ & $6.88 \pm 0.54^{\mathrm{b}}$ & $0.00 \pm 0.00^{\mathrm{e}}$ & $0.00 \pm 0.00^{\mathrm{e}}$ & $6.00 \pm 0.00^{\mathrm{cd}}$ & $6.50 \pm 0.58^{\mathrm{bc}}$ & $20.50 \pm 0.58^{\mathrm{a}}$ \\
\hline $\begin{array}{l}\text { Pseudomonas luteola } \\
\text { Photobacterium }\end{array}$ & $7.00 \pm 0.00^{\mathrm{ef}}$ & $9.38 \pm 0.41^{\mathrm{c}}$ & $8.50 \pm 0.50^{\mathrm{cd}}$ & $5.75 \pm 0.43^{\mathrm{f}}$ & $7.75 \pm 0.50^{\mathrm{de}}$ & $20.50 \pm 1.73^{\mathrm{b}}$ & $23.00 \pm 1.41^{\mathrm{a}}$ \\
\hline damselae & $8.50 \pm 0.50^{\mathrm{b}}$ & $0.00 \pm 0.00^{\mathrm{e}}$ & $6.00 \pm 0.00^{\mathrm{d}}$ & $6.50 \pm 0.50^{\text {cd }}$ & $7.50 \pm 0.58^{\mathrm{bc}}$ & $29.25 \pm 0.96^{\mathrm{a}}$ & $28.75 \pm 1.44^{\mathrm{a}}$ \\
\hline
\end{tabular}

*Different letters $(a-f)$ in the same line shows significant differences $(p<0.05)$.

Vibrio vulnificus is a dangerous species of bacteria of the genus Vibrio and is widely distributed in freshwater and seawater (Liu et al. 2019). Vibrio bacteria are not very common in food poisoning; but it is one of the important bacteria due to their lethal effects. In particular, seafood is high-risk food for this bacterium. Since it can survive in frozen foods, it can easily reproduce and cause poisoning, especially in foods that are not properly stored after thawing.
Thyme hydrosol was the most effective hydrosol on growth inhibition of $V$. vulnificus $(6.88 \mathrm{~mm})$. Orange and mandarin peel hydrosols showed statistically similar inhibition zones against $V$. vulnificus. Tetracycline was a more effective antibiotic than vancomycin against all bacteria tested. Elmahdi et al. (2016) reported that Vibrio vulnificus are resistant to antibiotics such as penicillin and tetracycline. In the present study, thyme hydrosol showed a greater 
effect than the test antibiotic vancomycin, which is an important result against a resistant bacterium. Thyme and mandarin peel showed a similar effect with vancomycine on growth inhibition of $V$. vulnificus.

Among hydrosols, the impact of orange and mandarin peel hydrosols on $P$. damselae was the highest. Both hydrosols were also showed statistically similar inhibition zones on the growth of P. damselae.

The MIC of hydrosols against food-borne bacteria was generally $50 \mathrm{mg} / \mathrm{mL}$. Shaddock peel and mandarin peel exerted more than $50 \mathrm{mg} / \mathrm{mL}$ of MIC against $S$. aureus and $K$. pneumonia.

Table 2. Minimum inhibitory concentration (MIC) of plant hydrosols against fish spoilage and food-borne bacteria.

\begin{tabular}{lccccc}
\hline \multirow{2}{*}{ Microorganisms } & Orange peel & Thyme & Pomegranate peel & Shaddock peel & Mandarin peel \\
\cline { 2 - 6 } Staphylococcus aureus & 50 & 50 & 50 & $>50$ & 50 \\
Salmonella Paratyphi A & 50 & 50 & 50 & 50 & 50 \\
Klebsiella pneumoniae & 50 & 50 & 50 & 50 & $>50$ \\
Vibrio vulnificus & 50 & 50 & $>50$ & 50 & 50 \\
Pseudomonas luteola & 50 & 50 & $>50$ & 50 \\
\hline
\end{tabular}

Öztürk et al. (2016) found that thymol was the major compound in thyme hydrosols and thyme hydrosol showed the antibacterial activity for the decontamination of the iceberg lettuce. Studies on the antimicrobial effects of pomegranate peel extract are also available (Kharchoufi et al. 2018). Hydrosols generally have alcohol and acids, in particular, octanoic, nonanoic and dodecanoic acids. They show antibacterial activity due to these components (Shen et al. 2017). In a study (Al-Turki 2007) examining the effects of different plant hydrosols on Bacillus subtilis and Salmonella enteritidis garlic, thyme, sage, mint, and pepper hydrosols showed an antibacterial effect. Similarly, (Acheampong et al. 2015) searched the antimicrobial potency of some hydrosols of leaves against Escherichia coli, Staphylococcus aureus, Candida albicans, Bacillus subtilis, and Enterococcus faecalis and they reported that fresh fruit peels of Citrus aurantifolia exhibited antimicrobial activity against all the tested organisms. In the current study, among hydrosols investigated, thyme and pomegranate peel hydrosols appeared to be more effective than other hydrosols, although the effect of hydrosols on the growth of bacteria depended on bacterial strains. This is thought to vary due to the components contained in the hydrosols.

In the present study, hydrosols of waste materials and by-products with antimicrobial properties were examined as alternative antimicrobial agents against common food-borne and fish spoilage bacteria. According to the results of the present study, it was seen that the antimicrobial effect of hydrosols varied depending on bacterial strains and the highest growth inhibitions was observed from thyme and pomegranate peel hydrosols.
The study results revealed that hydrosol which is regarded as waste in the production of essential oils could be evaluated as antibacterial agents.

\section{Acknowledgments}

This work has been financially supported by the Kırşehir Ahi Evran University, Department of Scientific Research Projects (Project ID: KMY.A4.19.003) of Turkey and the authors also gratefully acknowledge the support provided by Kurşehir Ahi Evran University.

\section{References}

Alexandre EMC, Silva S, Santos SAO, Silvestre AJD, Duarte MF, Saraiva JA, Pintado M. 2019. Antimicrobial activity of pomegranate peel extracts performed by high pressure and enzymatic assisted extraction. Food Res Int. 115(2019):167-176.

doi:10.1016/j.foodres.2018.08.044

Acheampong A, Borquaye LS, Acquaah SO, Osei-Owusu J, Tuani GK. 2015. Antimicrobial activities of some leaves and fruit peels hydrosols. Int. J. Chem. Biol. 1(3):158-162.

Ali A, Chen Y, Liu H, Yu L, Baloch Z, Khalid S, Zhu J, Chen L. 2019. Starch-based antimicrobial films functionalized by pomegranate peel. Int $\mathrm{J}$ Biol Macromol. 129(2019):1120-1126.

doi:10.1016/j.ijbiomac.2018.09.068

Al-Turki AI. 2007. Antibacterial effect of thyme, peppermint, sage, black pepper and garlic hydrosols against Bacillus subtilis and Salmonella enteritidis. J Food Agric Environ. 5(2):92-94.

Altınok İ, Balta F, Çapkın E, Kayış S. 2007. Disease of rainbow trout caused by Pseudomonas luteola. Aquaculture. 273(4):393-397. doi:10.1016/j.aquaculture.2007.10.025

Çiçek M, Hasçelik G, Müştak HK, Diker KS, Şener B. 2016. Accurate diagnosis of Pseudomonas luteola in 
routine microbiology laboratory: on the occasion of two isolates. Microbiology Bulletin. 50(4): 621-624. doi: $10.5578 / \mathrm{mb} .27618$

D'Amato S, Serio A, López CC, Paparella A. 2018. Hydrosols: biological activity and potential as antimicrobials for food applications. Food Control. 86(2018):126-137. doi:10.1016/i.foodcont.2017.10.030

Elmahdi S, DaSilva LV, Parveen S. 2016. Antibiotic resistance of Vibrio parahaemolyticus and Vibrio vulnificus in various countries: A review. Food Microbiol. 57(2016):128-134. doi:10.1016/j.fm.2016.02.008

Kharchoufi S, Licciardello F, Siracusa L, Muratore G, Hamdi M, Restuccia C. 2018. Antimicrobial and antioxidant features of 'Gabsi' pomegranate peel extracts. Ind Crop Prod. 111(2018):345-352. doi:10.1016/j.indcrop.2017.10.037

Kumar ARM, Kannan M, Nataraj G. 2020. A study on performance, emission and combustion characteristics of diesel engine powered by nano-emulsion of waste orange peel oil biodiesel. Renewable Energy. 146(2020):1781-1795. doi:10.1016/j.renene.2019.06.168

Liu R, Lian Z, Hu X, Lü A, Sun J, Chen C, Liu X, Song Y, Yiksung Y. 2019. First report of Vibrio vulnificus infection in grass carp Ctenopharyngodon idellus in China. Aquaculture. 499(2019):283-289.

doi:10.1016/j.aquaculture.2018.09.051

Moon T, Wilkinson JM, Cavanagh HMA. 2006. Antibacterial activity of essential oils, hydrosols and plant extracts from Australian grown Lavandula spp. Int J Aromatherapy. 16(1),9-14. doi:10.1016/j.ijat.2006.01.007

Murray PR, Baron EJ, Pfaller MA. 1995. Manual of chinical microbiology, 6th ed. Washington DC: ASM 1995.

Oboh G, Ademosun AO. 2011. Shaddock peels (Citrus maxima) phenolic extracts inhibit $\alpha$-amylase, $\alpha$-glucosidase and angiotensin Iconverting enzyme activities: A nutraceutical approach to diabetes management. Diabetes \& Metabolic Syndrome: Clinical Research \&Reviews. 5(3):148-152. doi:10.1016/j.dsx.2012.02.008

Oboh G, Bello FO, Ademosun AO. 2014. Hypocholesterolemic properties of grapefruit (Citrus paradisii) and shaddock (Citrus maxima) juices and inhibition of angiotensin-1-converting enzyme activity. J Food Drug Anal. 22(4):477-484. doi:10.1016/j.jfda.2014.06.005

Otto MP, Foucher B, Dardare E, Gerome P. 2013. Sever catheter related bacteremia due to
Pseudomonas luteola. Med Maladies Infect. 43(4):170-171.

doi.10.1016/j.medmal.2013.01.013

Öztürk İ, Tornuk F, Aydoğan O, Durak MZ, Sağdıç O. 2016. Decontamination of iceberg lettuce by some plant hydrosols. LWT-Food Sc1 Technol. 74(2016):48-54. doi:10.1016/j.lwt.2016.06.067

Rajha HN, Mhanna T, Kantar SE, Khoury AE, Louka N, Maroun RG. 2019. Innovative process of polyphenol recovery from pomegranate peels by combining green deep eutectic solvents and a new infrared technology. LWT-Food Sc1 Technol. 111(2019):138-146. doi:10.1016/j.lwt.2019.05.004

Sabo VA, Knezevic P. 2019. Antimicrobial activity of Eucalyptus camaldulensis Dehn. plant extracts and essential oils: A review. Ind Crop Prod. 132(2019):413-429. doi:10.1016/j.indcrop.2019.02.051

Saleem M, Saeed MT. 2020. Potential application of waste fruit peels (orange, yellow lemon and banana) as wide range natural antimicrobial agent. Journal of King Saud University Science. 32(1):805-810 doi:10.1016/j.jksus.2019.02.013

Shen X, Chen W, Zheng Y, Lei X, Tang M, Wang H, Song F.2017. Chemical composition, antibacterial and antioxidant activities of hydrosols from different parts of Areca catechu L. and Cocos nucifera L. Ind Crop Prod. 96(2017):110-119. doi:10.1016/j.indcrop.2016.11.053

Śmigielski KB, Prusinowska R, Krosowiak K, Sikora M. 2013. Comparison of qualitative and quantitative chemical composition of hydrolate and essential oils of lavander (Lavandula angustifolia). J Essent Oil Res. 25 (4):291-299. doi:10.1080/10412905.2013.775080

Wu Y, Zhu C, Zhang Y, Li Y, Sun J. 2019. Immunomodulatory and antioxidant effects of pomegranate peel polysaccharides on immunosuppressed mice. Int $\mathrm{J}$ Biol Macromol. 137(2019):504-511. doi:10.1016/j.ijbiomac.2019.06.139

Yang X, Nisar T, Hou Y, Gou X, Sun L, Guo Y. 2018. Pomegranate peel pectin can be used as an effective emulsifier. Food Hydrocolloid. 85(2018):30-38. doi:10.1016/j.foodhyd.2018.06.042

Zhai X, Zhu C, Zhang Y, Sun J, Alim A, Yang X. 2018. Chemical characteristics, antioxidant capacities and hepatoprotection of polysaccharides from pomegranate peel. Carbohyd Polym. 202(2018): 461-469. doi:10.1016/j.carbpol.2018.09.013 